ISSN 1112-9867

http://www.jfas.info

\title{
A NUMERICAL ANALYSIS OF THE ENERGY BEHAVIOR OF A PARABOLIC TROUGH CONCENTRATOR
}

\author{
M. Ghodbane*, B. boumeddane \\ ${ }^{1}$ Mechanical Engineering Department, Saad DAHLAB University, Blida 1, Algeria
}

Received: 09 February 2016 / Accepted: 02 July 2016 / Published online: 01 Septembre 2016

\begin{abstract}
The solar power is a clean and a durable energy; there are several techniques for using them. When necessary to elevated temperatures of heat transfer fluid, this energy must concentration. This paper presents the efficiencies study of a linear solar concentrator of a parabolic trough type. This study was conducted on the device in Guemar area, this region is located in the state of El-Oued, which it is found in the south-east of Algeria. Six typical days were selected to conduct the study in them. The solar collector has been studied optically and thermally. The optical study was using SolTrace. Matlab was used as device of programmation to solve the non-linear system of mathematical equations. The method of finite differences in the implicit case was used as way of solution. The thermal efficiencies of the concentrator are very acceptable, it have exceeded $82 \%$.
\end{abstract}

Keywords: Solar energy; parabolic trough concentrator; modelisation; optical efficiency, thermal efficiency.

Author Correspondence, e-mail: ghodbanemokhtar39@yahoo.com

doi: http://dx.doi.org/10.4314/jfas.v8i3.2

Journal of Fundamental and Applied Sciences is licensed under a Creative Commons Attribution-NonCommercial 4.0 


\section{INTRODUCTION}

Algeria is the first country in Africa by area, over four-fifths of their territory is desert. Algeria has a very important energy source from its location. Figure (1) shows the average annual global radiation received on a horizontal surface in the national territory between 1992 and 2002.

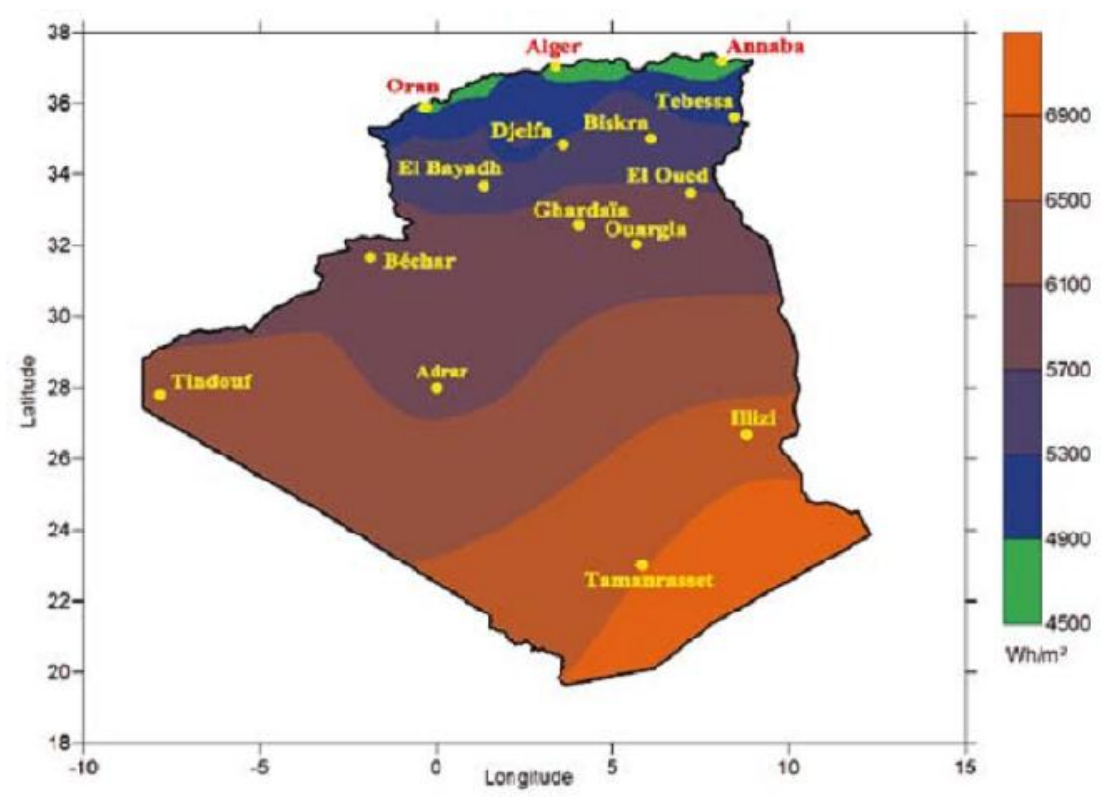

Fig.1. Average annual of global radiation received on a horizontal surface, period $1992-2002\left[\mathrm{Wh} / \mathrm{m}^{2}\right][1]$.

The annual duration of a solar radiation on almost all the national territory exceeds 2000 hours, which can reach 3900 hours (high plains and Sahara). Daily, the solar energy potential given on a horizontal surface of $1 \mathrm{~m}^{2}$ is around $5 \mathrm{KWh}$ over most of the country, where we find that the average energy received at the coastal region near $1700\left[\mathrm{KWh} / \mathrm{m}^{2}\right.$ / year], 1900 [KWh / $\mathrm{m}^{2} /$ year $]$ in the highlands, and $2650\left[\mathrm{KWh} / \mathrm{m}^{2} /\right.$ year $]$ in the south of the country $[2,3]$.

This paper is concerned with examining the effectiveness of a linear solar concentrator of a parabolic trough type. The main objective of this work is determining the water vapor temperature which can be reached through this collector in Guemar region, Algeria. This technology is mature and highly efficient; it is available today in Algeria (the hybrid power plant of Hassi R'Mel and the solar village of Adrar). An energy balance was chosen 
which is based on heat exchange between the four absorber tubes, the heat transfer fluid and glass tubes. A program Matlab was developed using the finite difference method in case implicit to simulate the performance of the concentrator. This study was done using real data from the parabolic trough collector of R'Mel Hassi hybrid power plant, Province of Laghouat, Algeria.

\section{THE PARABOLIC TROUGH CONCENTRATOR}

The parabolic trough solar concentrator has a circular absorber tubes of copper metal with a suitable selective layer located in the focal line of the parabola; the selective surface that has a high absorption coefficient and a good absorber of solar radiation, it has a high infrared emittance waves $[4,5]$. The receiver is surrounded by a glass envelope (glass). A direct incident solar radiation is focused by the mirrors on the receiver. A heat transfer fluid (HTF) circulates inside the receiver, in this case the fluid is water. The heated water where the temperature can exceed $160^{\circ} \mathrm{C}[6-8]$.

The parabolic trough concentrators are the most widely used linear concentrator for thermodynamic conversion of solar energy, especially in industrial and domestic areas where requiring an operating temperature between $80^{\circ} \mathrm{C}$ and $160^{\circ} \mathrm{C}$ [9]. For example, electricity production requires high temperatures of $400^{\circ} \mathrm{C}$ to $1200^{\circ} \mathrm{C}$. We can produce superheated steam in power plants with parabolic trough concentrators, where the temperature up to $1500{ }^{\circ} \mathrm{C}[7,8,10]$.

The parabolic trough concentrator is the most promising technologies to take the place of non-renewable energies (fossil fuels and nuclear energy), especially in the industrial sector (power plants, hybrid systems, desalination, air-conditioning, refrigeration, irrigation, etc.) $[8,11,12]$.

A gas / solar hybrid electric central was established in Algeria with German specifications in the region of Hassi R'Mel (Laghouat). This plant will combine parabolic trough concentrating solar power of $25 \mathrm{MW}$, an area of $180,000 \mathrm{~m}^{2}$, in conjunction with a gas turbine plant of $130 \mathrm{MW}$. 
The dimensions of the absorber tubes of this simulation are the same dimensions of receiver tubes of Hassi R'Mel Central. Table (1) shows the geometrical characteristics of the absorber tubes for a segment.

Table1. The geometrical characteristics of the absorber tubes.

\begin{tabular}{lc}
\hline Geometric characteristic & Value $[\mathbf{m m}]$ \\
\hline External diameter of the absorber $\left(\mathrm{D}_{\mathrm{A}, \mathrm{ext}}\right)$ & 70 \\
\hline Internal diameter of the absorber $\left(\mathrm{D}_{\mathrm{A}, \mathrm{int}}\right)$ & 65 \\
\hline External diameter of the glass $\left(\mathrm{D}_{\mathrm{V}, \mathrm{ext}}\right)$ & 115 \\
\hline Internal diameter of the glass $\left(\mathrm{D}_{\mathrm{V}, \mathrm{int}}\right)$ & 109 \\
\hline Mirror length $(\mathrm{L})$ & 12270 \\
\hline mirror width $(\mathrm{W})$ & 11900
\end{tabular}

Six days of the year were chose for such modeling. These days are the typical days of February, April, June, August, October and December for 2014. These measures were taken from the meteorological measurements archive of Guemar station; this station is locating in Guemar Airport [13]. Table (2) shows weather data for six days in the site of Guemar.

Table2. Meteorological data for Guemar site for six typical days.

\begin{tabular}{lccccc}
\hline month & Typical Day & $\mathbf{T}_{\max }\left({ }^{\circ} \mathbf{C}\right)$ & $\mathbf{T}_{\min }\left({ }^{\circ} \mathbf{C}\right)$ & $\mathbf{T}_{\text {aver }}\left({ }^{\circ} \mathbf{C}\right)$ & $\mathbf{V}_{\text {wind }}(\mathbf{m} / \mathbf{s})$ \\
\hline February & 16 & 26 & 11 & 18 & calm \\
\hline April & 15 & 29 & 14 & 22 & calm \\
\hline June & 11 & 35 & 21 & 28 & calm \\
\hline August & 16 & 44 & 26 & 35 & calm \\
\hline October & 15 & 26 & 18 & 22 & calm \\
\hline December & 10 & 19 & 05 & 12 & calm \\
\hline
\end{tabular}




\section{OPTICAL STUDY}

The optical modeling was performed using the SolTrace software; it is developed by the National Renewable Energy Laboratory (NREL), it is American laboratory [14]. The optical system of the concentrator is composed of two parts, the reflecting surface of the concentrator and four absorber tubes. The reflecting surface of the concentrator is modeled as a single mirror of parabolic section. The four absorber pipes are located in the focal line center of the concentrator to absorb the greatest possible amount of solar energy. Table (3) displays the optical parameters of the collector.

Table3. Optical characteristics of the absorber tubes.

\begin{tabular}{lc}
\hline Parameter & Value \\
\hline optical overall average error $\left(\sigma_{\text {optique }}\right)$ & 03 mrad \\
\hline Mirror reflection coefficient $\left(\rho_{\mathrm{m}}\right)$ & 0.92 \\
\hline Transmissivity of the glass & 0.945 \\
\hline Absorbion coefficient of the absorber tube $(\alpha)$ & 0.94 \\
\hline The emissivity of the absorber tube $\left(\varepsilon_{\mathrm{A}}\right)$ & 0.12 \\
\hline The emissivity of the glass $\left(\varepsilon_{\mathrm{V}}\right)$ & 0.935
\end{tabular}

The optical simulation is used to estimate the flow and thermal concentration incident on the surface of the absorber tubes. During the optical study took into account all of:

- The solar radiation value in every moment;

- The incidence angle of solar radiation on the reflecting mirror;

- The properties of each mirror (geometrically and optically);

- The properties of the absorber tubes (geometrically and optically). 


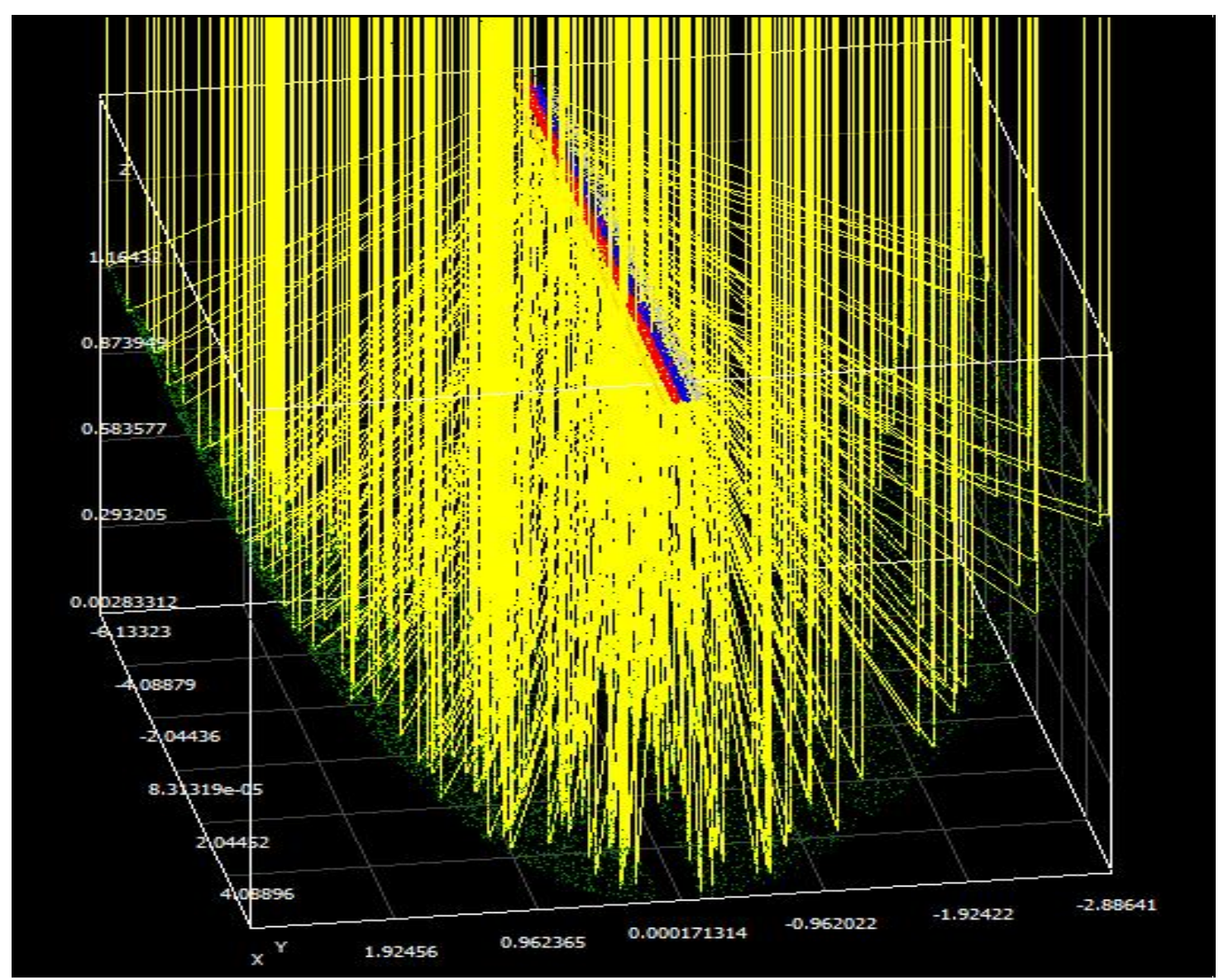

Fig.2. Parabolic trough concentrator schematic with SolTrace software.

It is assumed that the optical properties (coefficient of reflection, absorbency, etc.) are uniform over the entire reflecting surface. It is considered that the solar tracking is very precise; the opening of the hub is constantly perpendicular to the rays from the solar disk.

\section{THERMAL STUDY}

During the thermal modelisation of the solar thermal concentrator, numerical solution was used to simplify the energy balance equations. this model was used to estimate the variation of the output temperature of the liquid carrier of heat (water) based on the direct sunlight (DNI) in the site Guemar (61 meter altitude, latitude and longitude $33.51^{\circ} \mathrm{N} 6.78{ }^{\circ} \mathrm{E}$ ), Province of El Oued, Algeria.

Heat exchange occurs between three components: the heat transfer fluid, the absorber tubes and the glass tubes. The temperature modelisation is based on energy balances characteristic 
by differential equations of the three temperatures: $\mathrm{T}_{\mathrm{F}}$ (fluid), $\mathrm{T}_{\mathrm{V}}$ (glass) and $\mathrm{T}_{\mathrm{A}}$ (absorber tubes). These equations vary during the illumination time (t) for a length $(\mathrm{X})$ of the absorber. The discretization of method finite difference was chose for solving the nonlinear equations of heat balance at the absorber tubes. A computer program was developed in Matlab after discretization equations. For the calculation of energy balance was asks these assumptions:

- The heat transfer fluid is incompressible;

- The parabolic shape is symmetrical;

- The ambient temperature around the concentrator is uniform;

- The effect of the shadow of the mirror on the absorber tube is negligible;

- Solar flux at the absorber is uniformly distributed;

- The glass is considered opaque to infrared radiation;

- The exchanges by conduction in the absorber and the glass are negligible.

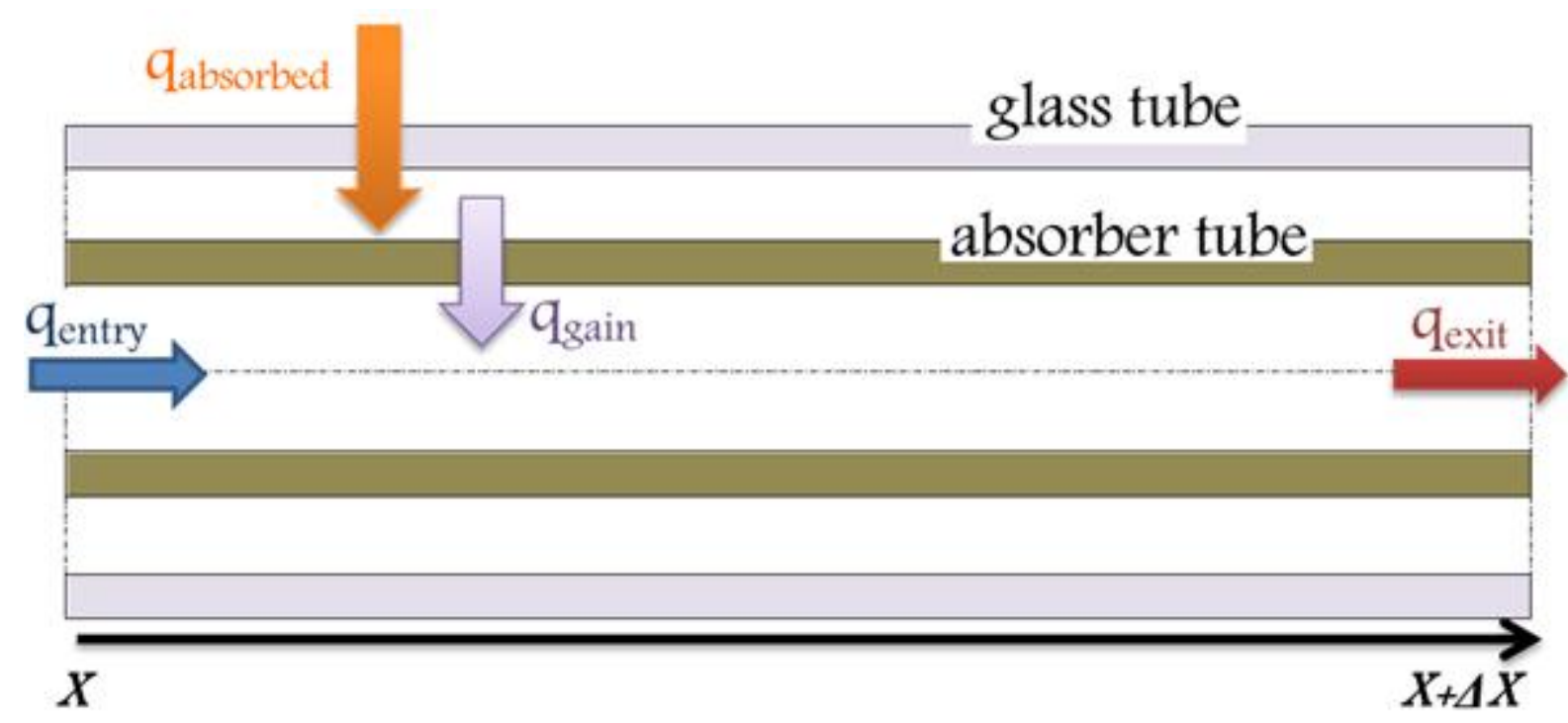


the ranking of absorber tubes
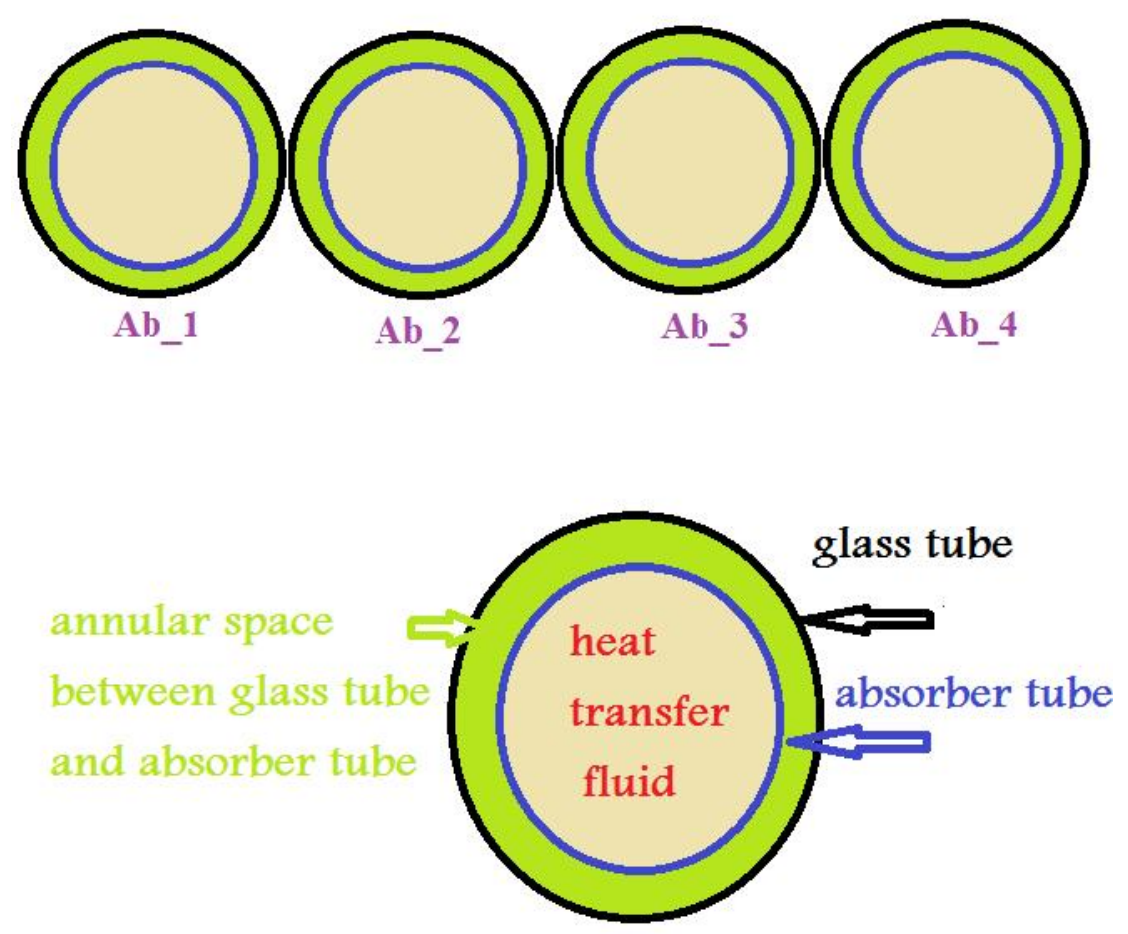

Fig.3. A surface element heat balance of the parabolic concentrator.

The optical efficiency of the concentrator was expressed as [15]:

$$
\eta_{o p t}=\rho_{m} \cdot \gamma \cdot \alpha \cdot K_{c a m}
$$

$\rho_{\mathrm{m}}$ is reflectance factor of the mirror; $\mathrm{K}_{\mathrm{cam}}$ is the angle of incidence correction factor modified; $\alpha$ is the absorbion coefficient of the absorber tubes and $\gamma$ is the intercept factor.

The heat flow transmitted to the fluid (the power gained to the collector " $q_{u}(W)$ )") is given by the following relationship $[16,17]$ :

$$
q_{u}=h_{F} \cdot A_{A, \text { int }}\left(T_{A}-T_{F}\right)
$$

Where, $\mathrm{A}_{\mathrm{A} \text {,int }}$ is the internal surface of absorber tube $\left(\mathrm{m}^{2}\right) ; \mathrm{T}_{\mathrm{A}}$ is the absorber tube temperature $\left({ }^{\circ} \mathrm{C}\right) ; \mathrm{T}_{\mathrm{F}}$ is the fluid's temperature $\left({ }^{\circ} \mathrm{C}\right)$.

$\mathrm{h}_{\mathrm{F}}$ is the coefficient of heat exchange by convection; it is often given by the relation follows [17]: 


$$
h_{F}=\frac{N u \times K_{F}}{D_{A, \text { int }}}
$$

$\mathrm{K}_{\mathrm{F}}$ is the thermal conductivity of the fluid; $\mathrm{Nu}$ is the Number of Nusselt. Gnielinski provides a linear interpolation in the transition region between the laminar and turbulent flow, in this case the useful transfer coefficient depends on two dimensionless Reynolds numbers and Prandtl $[18,19]$

$$
N u=\frac{\left(\frac{f}{8}\right)\left(\operatorname{Re}_{F}-1000\right) \operatorname{Pr}_{F}}{1+12.7 \sqrt{\frac{f}{8}}\left(\operatorname{Pr}^{2 / 3}-1\right)}
$$

the coefficient of friction $(f)$ is calculated from the relation of Petukhov [18, 19]

$$
f=\frac{1}{\left(0.079 \operatorname{Ln}\left(\operatorname{Re}_{F}\right)-1.64\right)^{2}}
$$

With $\left(\operatorname{Re}_{\mathrm{F}}\right)$ presents Reynolds number which is expressed by the following relation [17, 20]:

$$
\operatorname{Re}_{F}=\frac{4 \times \rho_{F} \times Q_{V}}{\pi \times D_{A, \text { int }} \times{ }_{F}}
$$

With $\quad F$ is the dynamic viscosity of the fluid $(\mathrm{Kg} / \mathrm{m} . \mathrm{s}) ; \rho_{\mathrm{F}}$ is the fluid density $\left(\mathrm{Kg} / \mathrm{m}^{3}\right)$

$A_{c}$ is the collector aperture area $\left(\mathrm{m}^{2}\right)$ and $Q_{v}$ is volume flow rate $\left(\mathrm{m}^{3} / \mathrm{s}\right)$.

The Prandtl number $(\operatorname{Pr})$ is given by $[17,21]$ :

$$
\operatorname{Pr}_{F}=\frac{{ }^{v} F}{a_{F}}
$$

With $\left(v_{F}\right)$ is the kinematic viscosity $\left(\mathrm{m}^{2} / \mathrm{s}\right)$ and $\left(\alpha_{F}\right)$ is the fluid thermal diffusivity $\left(\mathrm{m}^{2} / \mathrm{s}\right)$.

\subsection{Energy balance for the fluid}

The energy balance for the heat transfer fluid circulating in the absorber tube is expressed by the following relationship $[6,7]$ : 


$$
\rho_{F} \cdot C_{F} \cdot A_{A, \mathrm{int}} \cdot \frac{\partial T_{F}(X, t)}{\partial t}=q_{u}-\rho_{F} \cdot C_{F} \cdot Q_{v} \cdot \frac{\partial T_{F}(X, t)}{\partial X}
$$

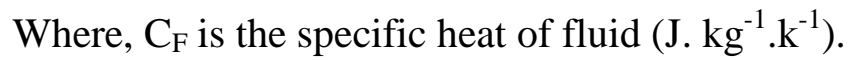

Initial conditions and boundary conditions of equation (8) are [6, 7]:

$$
\begin{aligned}
& \mathrm{T}_{\mathrm{F}}(0, \mathrm{t})=\mathrm{T}_{\mathrm{F}, \text { entry }}(\mathrm{t})=\mathrm{T}_{\mathrm{amb}}(\mathrm{t}) \\
& \mathrm{T}_{\mathrm{F}}(\mathrm{X}, \mathrm{t})=\mathrm{T}_{\mathrm{F} \text {,initial }}(\mathrm{t})=\mathrm{T}_{\mathrm{amb}}(0)
\end{aligned}
$$

All thermophysical characteristics of the water are a function of its temperature.

\subsection{Energy balance for the absorbers}

The energy balance for the absorber is given by the following equation $[6,7]$ :

$$
\rho_{A} \cdot C_{A} \cdot A_{A} \cdot \frac{\partial T_{F}(X, t)}{\partial t}=q_{\text {absorbed }}(t)-q_{\text {exit }}(X, t)-q_{u}(X, t)
$$

With, $\rho_{\mathrm{F}}$ is the fluid density $\left(\mathrm{Kg} \cdot \mathrm{m}^{-3}\right) ; \mathrm{C}_{\mathrm{A}}$ is the specific heat of absorber tube $\left(\mathrm{J} \cdot \mathrm{kg}^{-1} \cdot \mathrm{k}^{-1}\right)$ and $A_{A}$ is the difference between the inner surface and the outer surface of absorber tube $\left(\mathrm{m}^{2}\right)$. $\mathrm{q}_{\text {absorbed }}$ is the heat quantity absorbed by the absorber tube (W).

$$
q_{\text {absorbed }}=\rho_{m} \cdot \gamma \cdot A_{c} \cdot K_{\text {cam }} \cdot D N I
$$

Where, $\mathrm{A}_{\mathrm{C}}$ is the collector aperture area $\left(\mathrm{m}^{2}\right)$ and DNI is direct radiation $\left(\mathrm{W} \cdot \mathrm{m}^{-2}\right)$.

$\mathrm{q}_{\text {exit }}$ is the heat quantity of the fluid when it came out of the absorber tubes (W);

$$
\rho_{A} \cdot C_{A} \cdot A_{A} \cdot \frac{\partial T_{F}(X, t)}{\partial t}=q_{\text {absorbed }}(t)-q_{\text {exit }}(X, t)-q_{u}(X, t)
$$

The initial conditions for the equation (10) are:

$$
T_{A}(X, t)=T_{A, \text { initial }}(t)=T_{a m b}(0)
$$

\subsection{Energy balance of the glass tubes}

Similarly the energy balance for the glass is given by $[6,7]$ :

$$
\rho_{V} \cdot C_{V} \cdot A_{V} \cdot \frac{\partial T_{V}(X, t)}{\partial t}=q_{\mathrm{int}}(X, t)-q_{e x t}(X, t)
$$

Where, $\rho_{\mathrm{V}}$ is the glass density $\left(\mathrm{Kg} / \mathrm{m}^{3}\right) ; \mathrm{C}_{\mathrm{V}}$ is the specific heat of glass tube $(\mathrm{J} / \mathrm{kg} \cdot \mathrm{k})$ and $\mathrm{A}_{\mathrm{V}}$ is the difference between the inner surface and the outer surface of glass tube $\left(\mathrm{m}^{2}\right)$. 
$\mathrm{q}_{\text {int }}$ is the internal power (by convection and radiation) between absorber tube and glass tube (W);

$\mathrm{q}_{\mathrm{ext}}$ is the external power (by convection and radiation) between glass tube and the atmosphere $(\mathrm{W})$.

The initial condition of equation (14) is:

$$
T_{V}(X, t)=T_{V \text {,initial }}(t)=T_{a m b}(0)
$$

\subsection{Thermal efficiency}

The thermal efficiency of the concentrator was expressed as $[15,17]$ :

$$
\eta=\eta_{o p t}-\frac{U_{L} \cdot A_{A, e x t} \cdot\left(T_{A}-T_{a m b}\right)}{D N I \times A_{C}}
$$

With, $\mathrm{A}_{\mathrm{A} \text {,ext }}$ is the external surface of the absorber tube, $\mathrm{T}_{\mathrm{amb}}$ is the ambient temperature $(\mathrm{K})$ and $\mathrm{U}_{\mathrm{L}}$ is the heat loss coefficient $\left(\mathrm{W} / \mathrm{m}^{2} . \mathrm{K}\right)$.

\subsection{Heat loss}

The use of the solar concentrators to to focus the sun's rays can greatly reduce the size of the absorber tube, thereby reducing heat loss and allow increasing the efficiency of the system at high temperatures. In addition, the concentrators are significantly less expensive per unit area compared to flat plate collectors. The factor $\left(\mathrm{U}_{\mathrm{L}}\right)$ is the heat loss coefficient, it is expressed by:

$$
\begin{aligned}
\mathrm{U}_{\mathrm{L}}=\left(\frac{1}{\mathrm{C}_{1}\left[\frac{\mathrm{T}_{\mathrm{A}}-\mathrm{T}_{\mathrm{amb}}}{1+\mathrm{f}}\right]^{0,25}}+\frac{\mathrm{D}_{\mathrm{A}, \text { int }}}{\mathrm{D}_{\mathrm{A}, \mathrm{ext}} \times \mathrm{h}_{\mathrm{v}}}\right)^{-1} \\
+\left(\frac{\sigma\left(T_{A}^{2}+T_{a m b}^{2}\right) \cdot\left(T_{A}+T_{a m b}\right)}{\left[\varepsilon_{A}-0,04\left(1-\varepsilon_{A}\right)\left(\frac{T_{A}}{450}\right)\right]^{-1}-\left[\left(\frac{D_{A, \text { int }}}{D_{A, \text { ext }}}\right)\left(\frac{1}{\varepsilon_{V}}\right)\left(\frac{\mathrm{f}}{\varepsilon_{V}}\right)\right]}\right)
\end{aligned}
$$

Where, $\varepsilon_{\mathrm{A}}$ is the emissivity of the absorber tube; $\varepsilon_{\mathrm{V}}$ is the emissivity of the transparent glass envelope; $\sigma$ is Stefan-Boltzmann constant $\left(\sigma=5.670 .10^{-8} \mathrm{~W} / \mathrm{m}^{2} \cdot \mathrm{K}^{4}\right)$.

With the factor (f) takes into account the loss ratio of the wind, and which can be obtained by 
the following equation:

$$
\mathrm{f}=D_{A, \text { int }}^{-0,4}\left(1,61+1,3 \varepsilon_{A}\right) h_{v}^{-0,9} \exp \left[0,00325\left(T_{A}-273\right)\right]
$$

$\mathrm{C} 1$ is given by the following empirical expression:

$$
C_{1}=\frac{1,45+0,96\left(\varepsilon_{A}-0,5\right)^{2}}{D_{A, \text { int }}\left(\frac{1}{D_{A, \text { int }}^{0,6}-D_{A, \text { ext }}^{0,6}}\right)^{1,25}}
$$

The term $h_{v}$ is the convection coefficient of the wind; it is given by the following equation (according McAdams (1954)) [17, 18]

$$
h_{v}=5,7+3,8 \mathrm{~V}
$$

According Watmuff and al. (1977), $\mathrm{h}_{\mathrm{v}}$ can be obtained by the following equation [18]:

$$
h_{v}=2,8+3 V
$$

Where; $\mathrm{V}$ is the wind speed $\left(\mathrm{m} \cdot \mathrm{s}^{-1}\right)$.

This work was to model the concentrator by using the finite deference method in implicit model. The nonlinear algebraic equation is solved using the iterative method of Gaussian-Seidel. Algebraic equations were written in Matlab programming language.

\section{RESULTS AND INTERPRETATIONS}

The solar contributions are given for the town of Guemar. The concentration of solar radiation by using the parabolic trough collector produces the water vapor with a very high temperature. Figure (4) summarizes the direct solar radiation as a function of time for six days selected according to the semi-empirical model of Perrin BRICHAMBAUT [22]. 


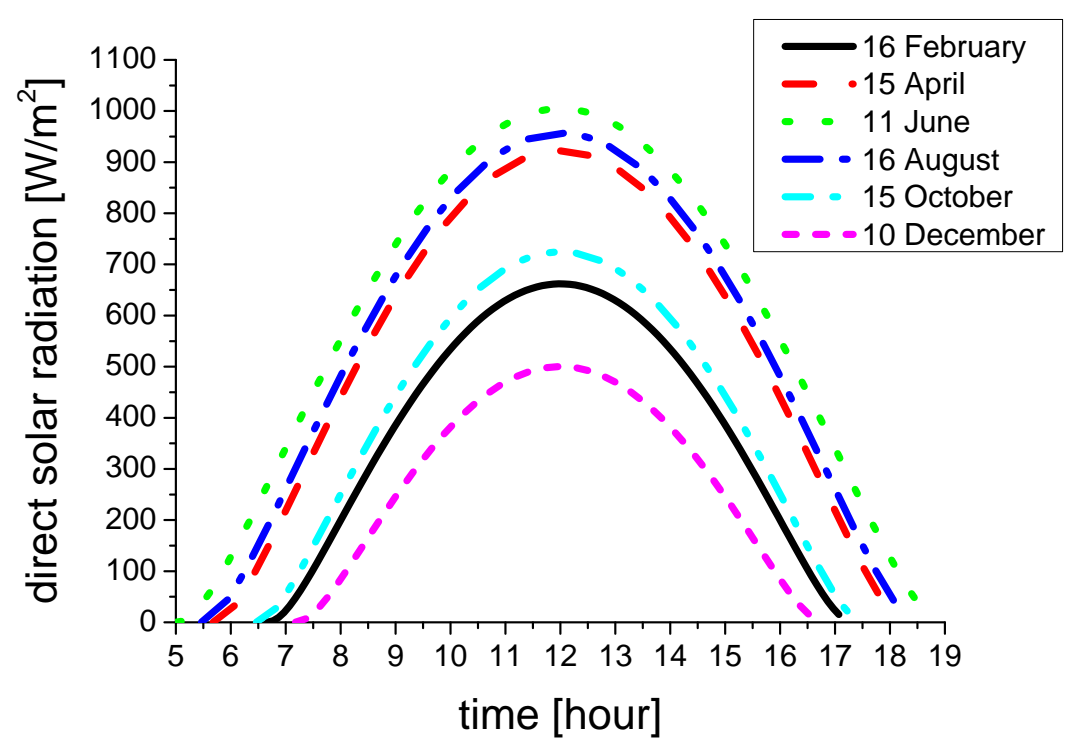

Fig.4. The evolution from direct sunlight (DNI) $\left[\mathrm{Wm}^{-2}\right]$.

Note that for the day of June 11, the direct solar radiation is maximal at the real solar noon, which can reach $1000\left[\mathrm{w} / \mathrm{m}^{2}\right]$.

The main objective of the optical modeling is the know concentration of power in the absorber tubes, and the evolution of the heat flux at the absorber according to a variation of the incidence angle of rays solar. Figures 5a-h show the contour of the average heat flux intensity with a direct solar radiation value equal to $700\left[\mathrm{~W} / \mathrm{m}^{2}\right]$.

$\underline{a}$

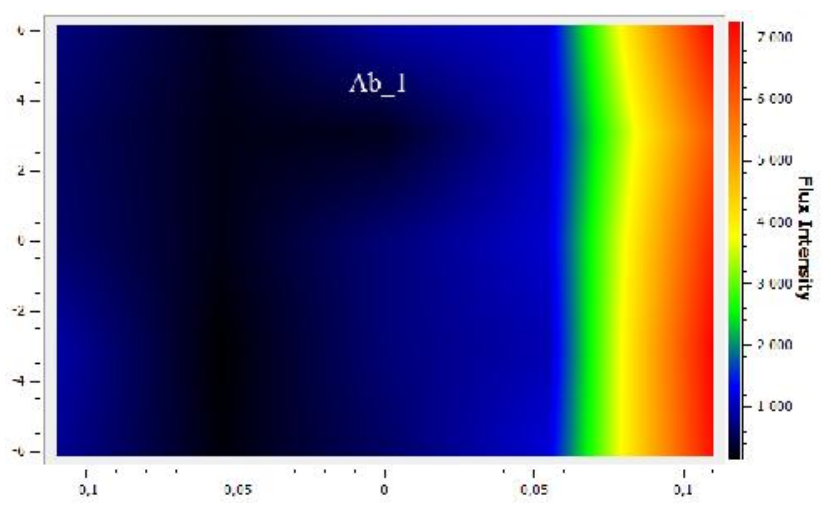

$\underline{c}$ $\underline{b}$

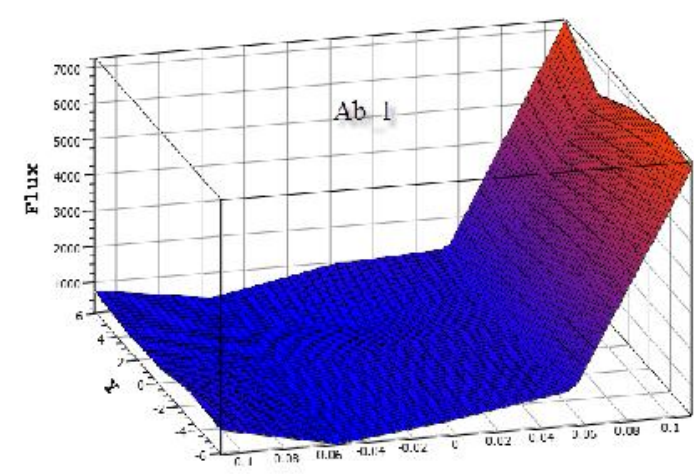



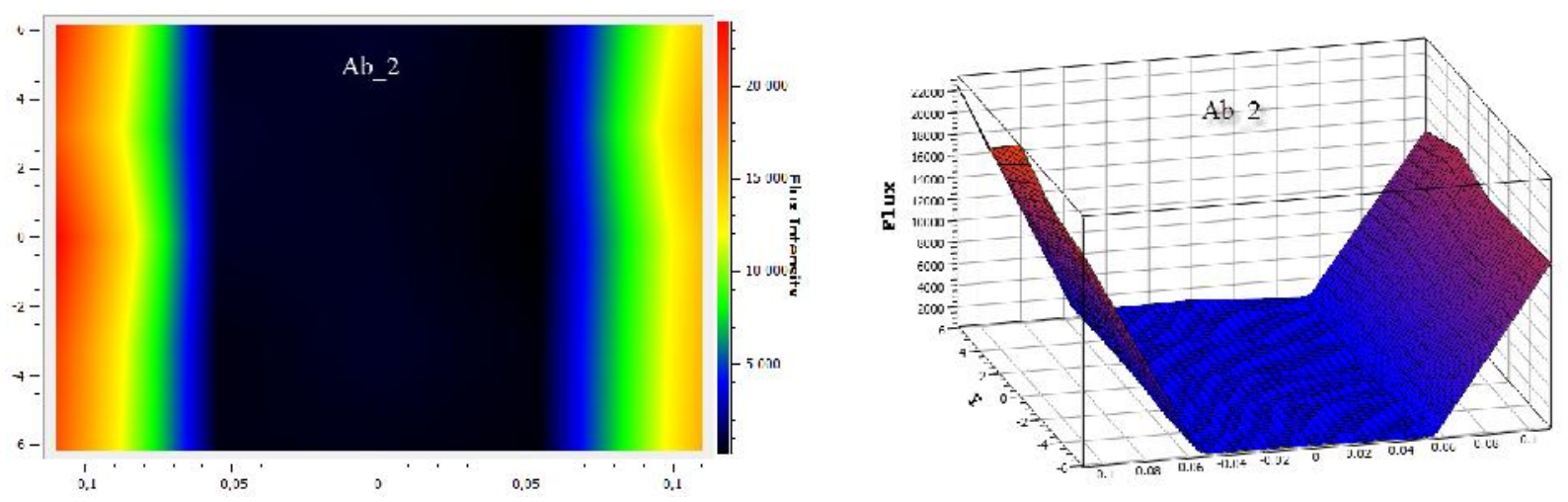

$\underline{\boldsymbol{e}}$

$f$
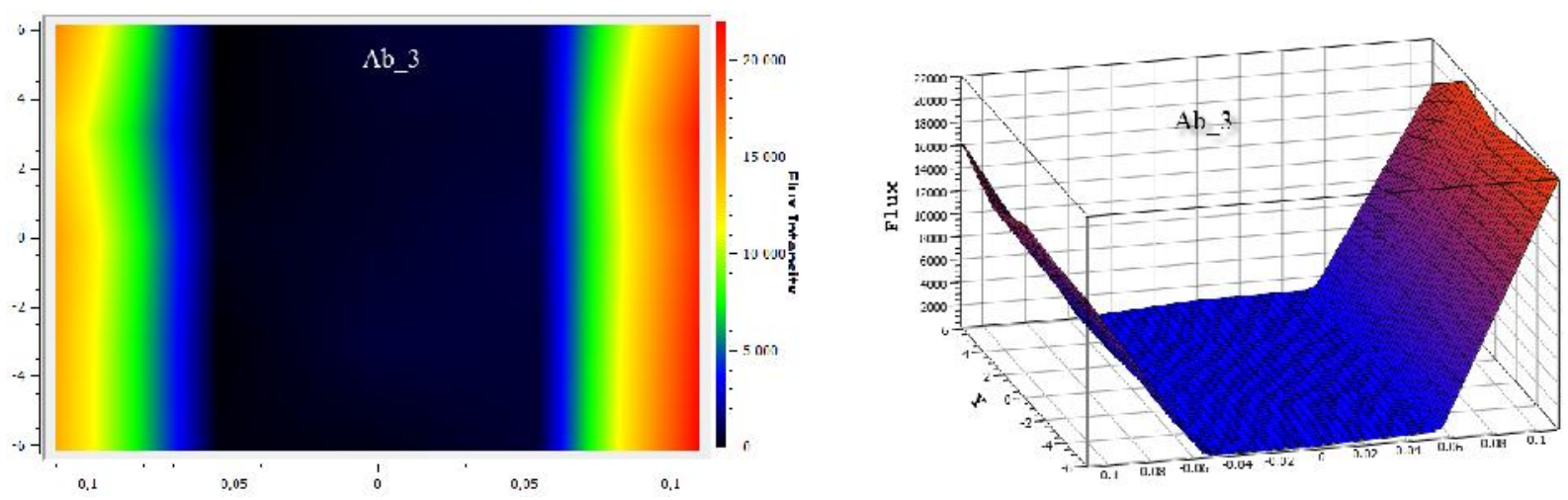

$g$

$\underline{h}$
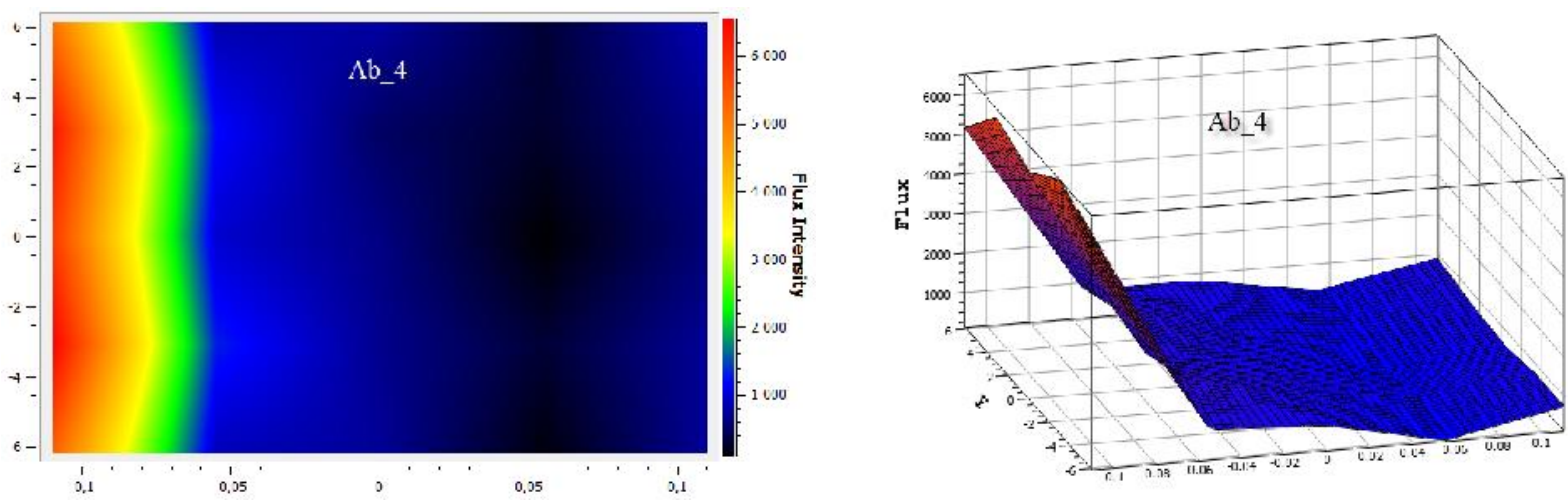

Fig.5. The contour and the distribution of the average flux density at the absorber tubes with $\mathrm{DNI}=700\left[\mathrm{~W} / \mathrm{m}^{2}\right]$. 
The optical efficiency is written according to the modified incidence angle. Figure (6) represents the variation of the optical efficiency as a function of true solar time.

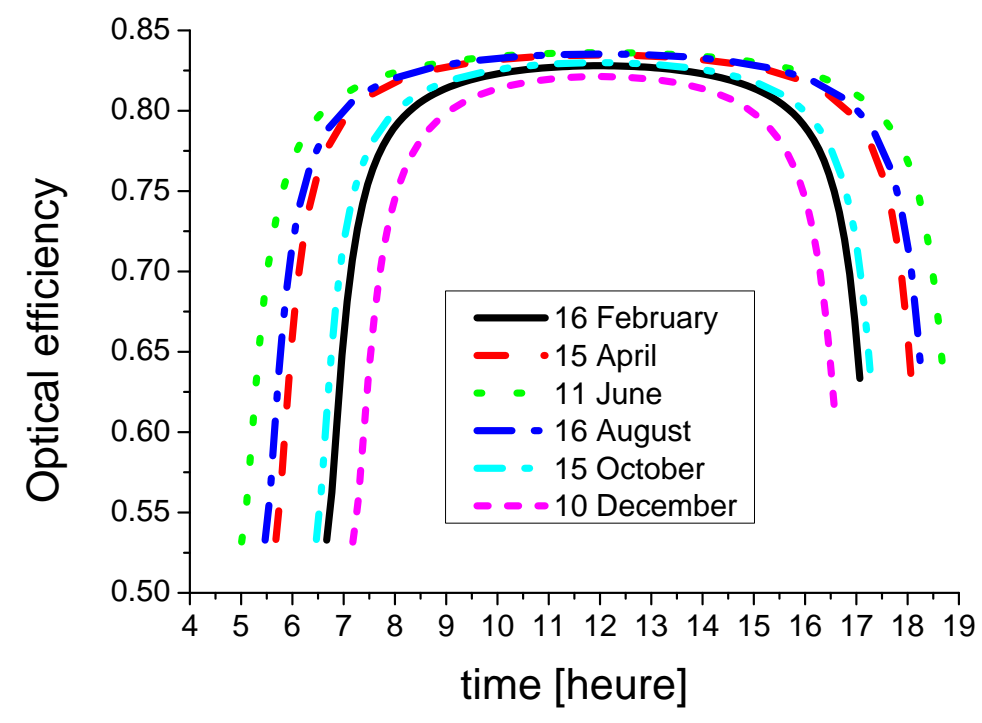

Fig.6. The evolution of optical efficiencies.

Figure (7) shows the evolution of the thermal efficiency as a function of time for six days of study.

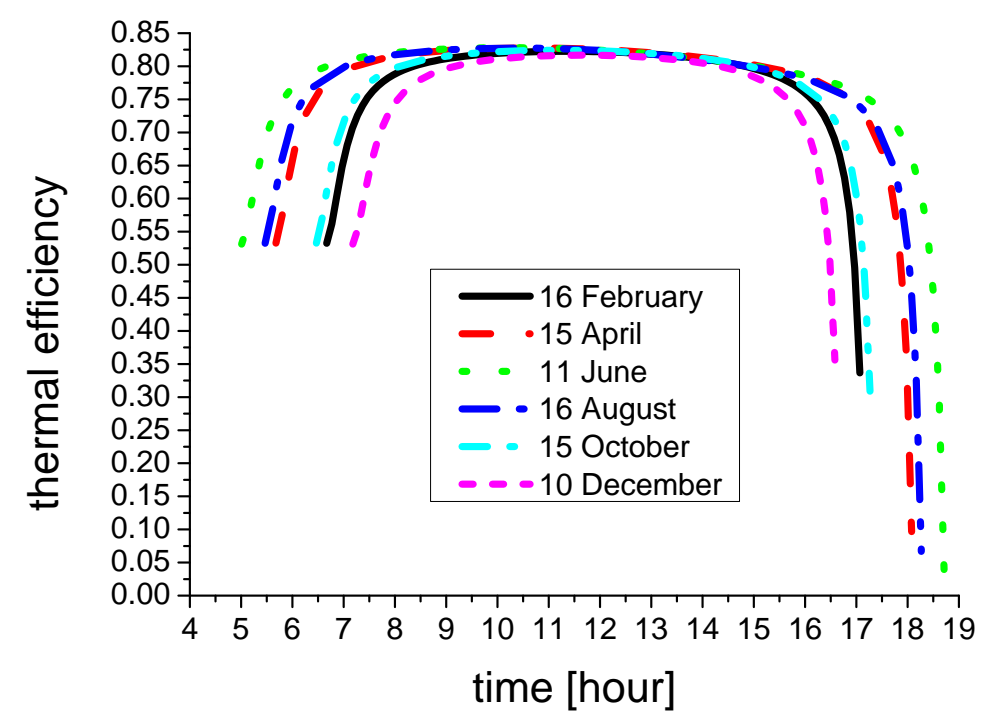

Fig.7. The evolution of thermal efficiencies.

The optical performance of collector is higher of $83.61 \%$. The maximum value of thermal 
efficiency can reach up $82.80 \%$, because the inlet temperature of water is almost identical to the ambient temperature, which thus corresponds to a very good thermal insulation and the lower heat loss to the atmosphere. This reduction in the thermal efficiency after the maximum value, is due to thermal losses believe that with increasing water temperatures respectively at the inlet and outlet of the absorber.

Figure (8) provides the changes in the quantity of heat absorbed in the level of absorber tubes of in watts.

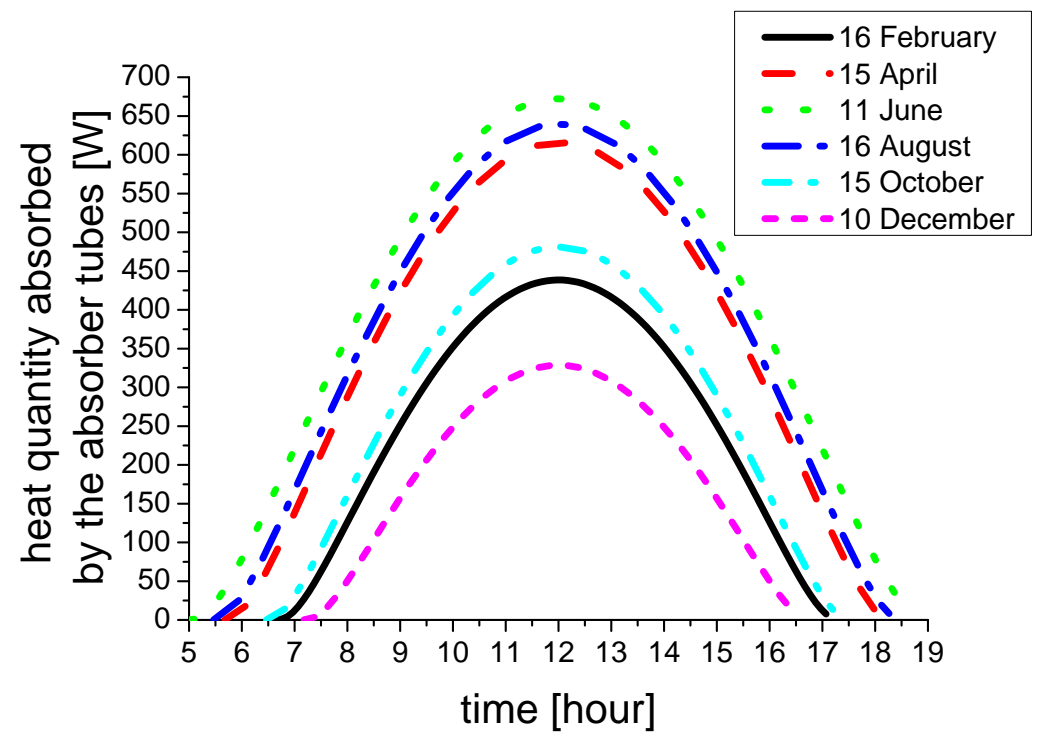

Fig.8. The evolution of heat quantity absorbed by the absorber tubes.

The tap water is used as heat carrier fluid. The average mass flow of the water in the interior of absorber tubes is equal to $0.015[\mathrm{~kg} / \mathrm{s}]$. The role of the heat carrier fluid is transporting heat from the source to the use. The water has a high heat capacity and it is fluid does not pollute the environment. During the simulation, the physical properties of the heat carrier fluid are varied depending on the temperature of the fluid at that moment. Figure (9) represents the evaluation of the fluid temperature at the outlet of absorber tubes according to true solar time. 


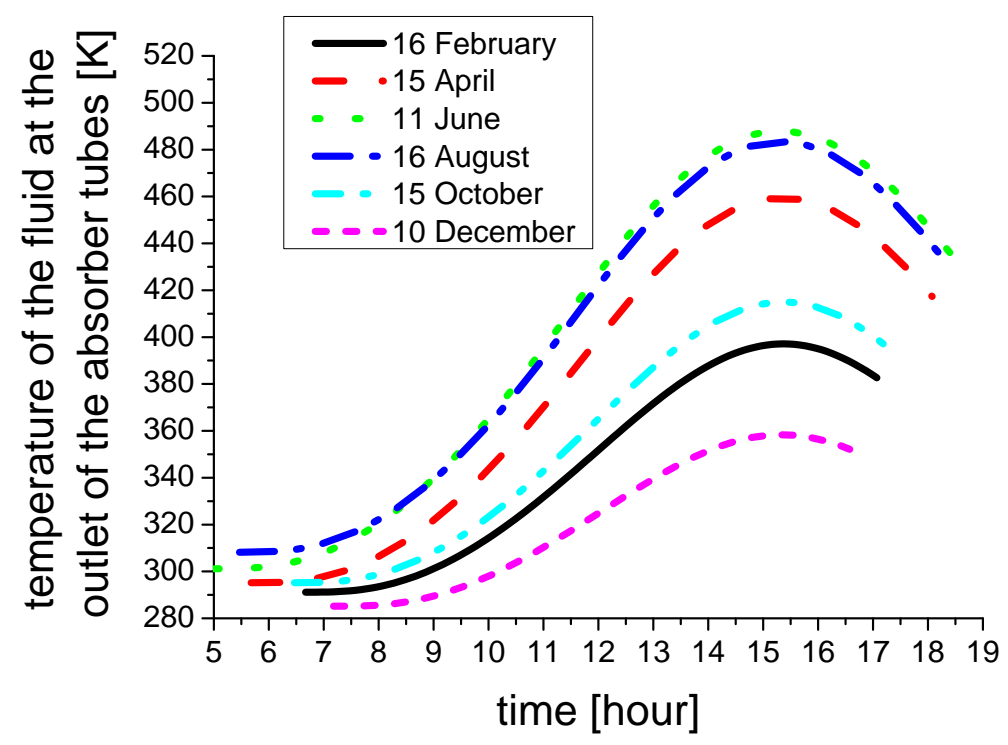

Fig.9. Evolution of fluid temperature at the outlet of the absorber tubes a function of time.

The water turns into steam at temperature up to $488[\mathrm{~K}]$ or more. The fluid temperature at outlet of the absorber tubes is inversely proportional to the direct sunlight, and it mainly depends with the heat quantity absorbed by absorbed tubes $\left(\mathrm{q}_{\text {absorbed }}(\mathrm{t})\right)$, which is based on optical and geometric parameters of concentrator.

So, the quantity of heat absorbed by the absorber tubes has a direct relationship with the direct radiation (DNI), this quantity is based on optical and geometrical parameters of the concentrator, and it is not entirely transmitted the heat transfer fluid, wherein a part is dissipated as heat loss between the absorber and the glass, and another portion between the glass and the ambient environment. Figure (10) shows the variation of thermal losses coefficient as a function of the difference in temperature between the absorber tube and the atmosphere. 


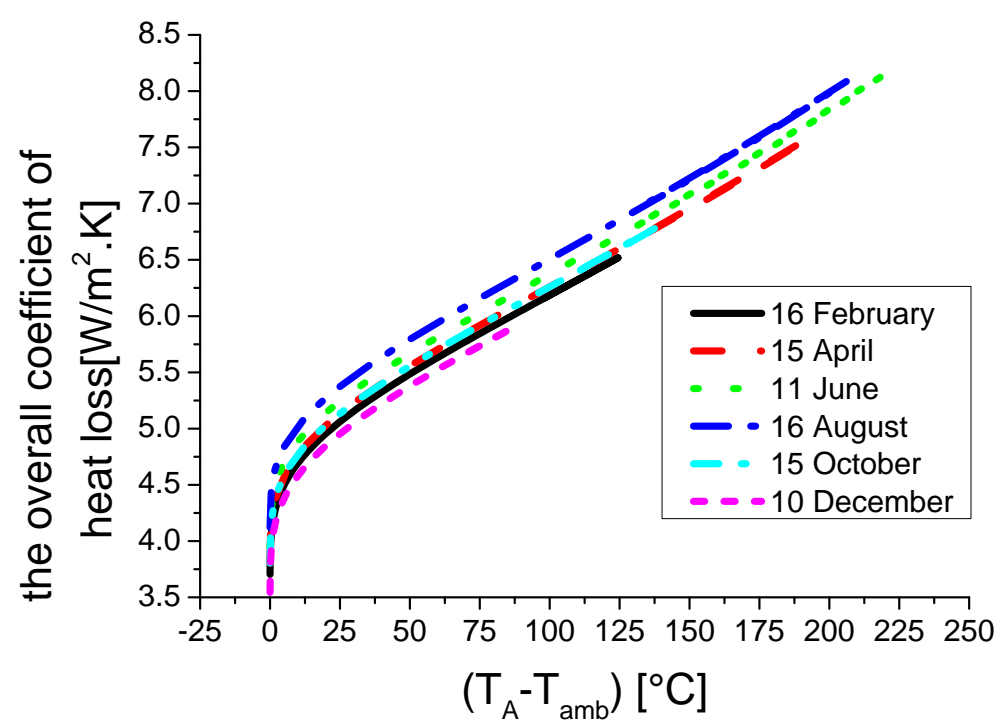

Fig.10. The evolution of heat loss coefficient.

The dependence of the heat loss coefficient with the absorber tube temperature is very clear. It is observed that the losses increase with the increase of the temperature of the absorber, so the absorber is the seat of heat loss. The creating vacuum between the absorber is the transparent glass envelope, could significantly reduce losses by convection. The glass is transparent to visible solar radiation but opaque to infra-red rayans (IR). Thus, the absorber tube is covered by a glass envelope, thus the radiative losses infra-red emission is greatly reduced.

It can be said that this study made it possible to calculate the thermal efficiency and fluid temperature at outlet of absorber tubes; this means it possible to evaluate the thermal performance of the collector. We can say that the incident solar radiation directly affects the performance of the concentrator. Weather conditions (wind speed, the ambient temperature, etc.) which vary from season to season influes on the performance of the solar concentrator.

The simulation results are very encouraging for the exploitation of solar energy in the field of water vapor exploitation in the site of Guemar, El Oued Province, Algeria. 


\section{CONCLUSION}

Along the year, Guemar and its suburbs have strong sunlight. The solar energy is natural, clean, non-polluting and inexhaustible energy. The application of solar renewable energy systems such as solar concentration systems in many industrial and domestic areas can solve many problems. These systems can also completely replace fossil fuels.

This work contains a simulation of a parabolic trough concentrator in the climatic conditions in Guemar region, El Oued Province, Algeria. The study is based on the numerical solution of the energy balance equations linked between the absorber tubes, the heat transfer fluid (water) and the glass tubes. The optical performance of collector has exceeded $83.61 \%$; it is attained to $83.621 \%$. The thermal efficiency stopped at $82.8 \%$. This numerical study shows that the fluid temperature exceeds $488[\mathrm{~K}]$, we note that there is a change in the water liquid to vapor. This change is caused by a change in the pressure, in the temperature and in the volume of the heat transfer fluid. Finally, the results are very encouraging for the use of solar energy in the study area.

\section{REFERENCES}

[1] YAICHE M R, BOUHANIK A. Atlas Solaire Algerien: Portail Des Energies Renouvelables, Centre de Développement des Energies Renouvelables, 2002, pp. 16.

[2] Ministry of energy. Potentiels National des Energies Renouvelables. Web site: http://www.mem-algeria.org/francais/index.php?page=potentiels-national-des-energiesrenouvelables, 27/08/2015.

[3] GHODBANE M, BOUMEDDANE B, MOUMMI N, LARGOT S, BERKANE H. Study and numerical simulation of solar system for air heating, J Fundam Appl Sci, 2016, 8, (1), 4160. doi: http://dx.doi.org/10.4314/jfas.v8i1.3

[4] Wikipedia. Emissivité. Web site:

http://fr.wikipedia.org/wiki/\%C3\%89missivit\%C3\%A9, 2015.

[5] GOUHMAN G, KOUDRACHOVA M, MILEVSKAYA N, EYDINOVA F. Surfaces sélectives: propriétés optiques et estimation de l'efficacité énergétique dans l'application aux récepteurs $\quad$ solaires, $\quad$ Phys. Appl, 1980, 15, 393-396. 
http://dx.doi.org/10.1051/rphysap:01980001503039300

[6] GHODBANE M, BOUMEDDANE B, LARGOT S. Etude optique et thermique d'un concentrateur cylindro-parabolique en site d'Alger, Algérie, presented at IXth International Congress on Renewable Energy and the Environment, Djerba, Tunisie, 18-20 March 2015. http://dx.doi.org/10.13140/RG.2.1.1609.5763

[7] GHODBANE M, BOUMEDDANE B. Numerical modeling of a parabolic trough solar collector at Bouzaréah, Algeria, Int J Chem Pet Sci. 2015, 4, (2), 11-25.

[8] GHODBANE M, BOUMEDDANE B, LARGOT S. Simulation Numérique d'un Concentrateur Cylindro-Parabolique en El Oued, Algérie, International Journal of Scientific Research \& Engineering Technology (IJSET), 2015, 3, (2), 68-74.

[9] AL-RUBAIAN A I, HAMAD A F. Performance of single Axis tracking solar parabolic trough in Riyadh Saudi Arabia, presented at World renewable energy congress VIII, 2004.

[10] VAILLANT J R. Utilisation et promesse de l'énergie solaire, Edition Eyrolles, Paris, 1978.

[11] FERNA`NDEZ-GARCI’A A, ZARZA E, VALENZUELA L, PE`REZ M. Parabolictrough solar collectors and their applications, Renewable \& Sustainable Energy Reviews, 2010, 14, 1695-1721. http://dx.doi.org/10.1016/j.rser.2010.03.012

[12] HEPBASLI A, ALSUHAIBANI Z. A key review on present status and future directions of solar energy studies and applications in Saudi Arabia, Renewable and Sustainable Energy Reviews. 2011, 15, 5021-5050. http://dx.doi.org/10.1016/j.rser.2011.07.052

[13] WEATHER UNDERGROUND. Weather History for Guemar airport station. Web site: http://www.wunderground.com, 2014.

[14] WENDELIN T, DOBOS A, LEWANDOWSKI A, Technical Report, SolTrace: A RayTracing Code for Complex Solar Optical Systems, Technical Report, October 2013.

[15] YOGI D G, KREITH F, KREIDER J F. Off-Normal Incidence Effects: in Principles of solar engineering, Taylor \& Francis, 2nd Edition, 1999, pp. 139.

[16] KALOGIROU S. Thermal analysis of parabolic trough collectors: in solar energy engineering- processes and systems, Thermal analysis of parabolic trough collectors, 1st edition, 2009, pp. 199-202. 
[17]GHODBANE M, BOUMEDDANE B, SAID N. A linear Fresnel reflector as a solar system for heating water: theoretical and experimental study, Case Studies in Thermal Engineering, 2016, 8, 176-186. http://dx.doi.org/10.1016/j.csite.2016.06.006

[18] DUFFIE J A, BECKMAN W A. Solar Energy of Thermal Processes, 4th edtition: John Wiley \& Sons, 2013.

[19] CENGEL Y A. Heat Transfer: a Practical Approach, 2nd edition, 2003.

[20] WIKIPEDIA. Reynolds number, Web site:

http://en.wikipedia.org/wiki/Reynolds_number, 2015.

[21]WIKIPEDIA. Prandtl number, site web: http://en.wikipedia.org/wiki/Prandtl_number, 2014.

[22]GHODBANE M, BOUMEDDANE B, LARGOT S. Developpement d'un programme informatique pour la simulation du rayonnement solaire recu par une surface inclinee, presented at Journée d'étude sur les énergies renouvelables et leurs applications, Université d'El Oued, Avril 2015.

\section{How to cite this article:}

Ghodbane M, Boumeddane B. A numerical analysis of the energy behavior of a parabolic trough concentrator. J. fundam. appl. sci., 2016, 8(3), 671-691. 